
Ljubica Spaskovska - 9781526106339 Downloaded from manchesterhive.com at $04 / 26 / 2023$ 10:32: 07 AM via free access 


\section{The last Yugoslav generation}

\section{MANCHESTER 1824}

Manchester University Press 
Ljubica Spaskovska - 9781526106339 Downloaded from manchesterhive.com at $04 / 26 / 2023$ 10:32: 07 AM via free access 


\title{
The last Yugoslav generation
}

\author{
The rethinking of youth politics and cultures \\ in late socialism
}

Ljubica Spaskovska

Manchester University Press 
Copyright (C) Ljubica Spaskovska 2017

The right of Ljubica Spaskovska to be identified as the author of this work has been asserted by her in accordance with the Copyright, Designs and Patents Act I988.

Published by Manchester University Press

Altrincham Street, Manchester Mi 7JA

www.manchesteruniversitypress.co.uk

British Library Cataloguing-in-Publication Data

A catalogue record for this book is available from the British Library

Library of Congress Cataloging-in-Publication Data applied for

ISBN 978 I 526I 063 I 5 hardback

First published 2017

The publisher has no responsibility for the persistence or accuracy of URLs for any external or third-party internet websites referred to in this book, and does not guarantee that any content on such websites is, or will remain, accurate or appropriate.

Typeset by Out of House Publishing

Printed in Great Britain

by CPI Group (UK) Ltd, Croydon CRo 4 YY 